Multidisciplinary

SCIENTIFIC JOURNAL OF MARITIME RESEARCH

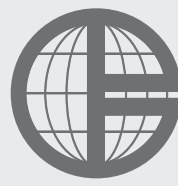

University of Rijeka

Faculty of Maritime

Studies Rijeka
Multidisciplinarni

znanstveni časopis

POMORSTVO

\title{
A Simple Mathematical Model for Refrigerating Compressor Optimization
}

\author{
Darko Glujić, Predrag Kralj, Dragan Martinović \\ University of Rijeka, Faculty of Maritime Studies, Studentska 2, 51000 Rijeka, Croatia, e-mail: darko@db-info.hr; pkralj@pfri.hr; dragec@pfri.hr
}

\section{ARTICLE INFO}

Preliminary communication

Received 1 March 2018

Accepted 4 June 2018

Key words:

Optimization

Refrigerating compressor

Thermal insulation

Costs

\section{Introduction}

Marine refrigerating systems application on board ships is standard for a number of years, with the provision being the most applied system on board ships [1]. Although this system could seem to be rather complex, for the purpose of such basic modelling, as used in this paper, it could be simplified.

The provision system usually consists of several cooling chambers, each of them having different temperature, volume, lights, air circulation etc. The simplified model used in this paper will have only one chamber having mediate temperature, insulation, thermal coefficients and volume. Such a simplification could be made even for a number of compressors. Namely, even if there are two of them, usually only one is working, while the other is 'on standby'. A mathematical model of the refrigerating system having just one chamber has been presented by Brito et al. [2]. Although the paper tries to calculate each and every thermal load of the system, some simplifications are made. Simplified mathematical models are generally used in the thermal processes analysis: certain parameters could be neglected; sometimes mean values are used, as has been done in the papers by Milošević et al. [3, 4] and Kralj et al. [5].
In case of provision store refrigerating system on board a ship, exact thermal loads could not be determined, unless there has been a measurement performed on an actual ship: thermal load with intentionally or unintentionally introduced air and with human work could not be determined exactly because it strongly depends on the way the cook uses the chamber; the thermal load with metabolic respiration depends on the fact whether the food is being loaded fresh or frozen; the thermal load with electrical equipment, namely fans, lights and defrosting heaters also varies a lot because there could be a chamber with natural evaporation, the number of lights depends on the size of the chamber and perhaps the chamber could be entered into without switching the lights on etc. That is the reason why the model in this paper deals with the thermal load through the chamber walls only.

The criterion for the optimization model in this paper would be equipment costs, the one mostly appraised and used by shipowners. Obviously, one could select cheap equipment with a shorter operating life, while the other could choose the most expensive equipment with low operating costs and long operating life. The approach used in this paper is to minimize the total costs. 
The process is simple enough but the problem rises with the equipment standardization. Namely, most of the countries with a strong shipbuilding industry have developed certain standards of production, as have the major equipment producers. In this respect, the optimal but nonstandard product could increase the investment costs in such a manner that the installation of a standard model seems a more profitable solution. However, the model proposed in this paper could, at least, point-out which of the standard equipment is the closest to the optimal one.

The optimal equipment would, furthermore, result in the reduced energy consumption and consequently, reduced environment pollution as suggested in the papers $[6,7,8]$. Additionally, the optimized equipment could become a part of an integrated ship managing system as suggested by Martinović et al. [9, 10] and Kralj [11] and could be easily integrated in the ship cogeneration system [12]. Furthermore, if there is an integrated managing system, advanced fault avoiding information systems could be implemented $[13,14]$.

\section{A Simplified Mathematical Model}

The standard model of any equipment total costs is given in the expression

$$
U=I+E
$$

where, in case of the refrigerating equipment, $U[\$]$ stands for total costs, $I$ [\$] stands for investment costs of the compressor, condenser, expansion valves, evaporators, piping with all the necessary equipment and, insulation or in short term, the costs of equipment, and $E[\$]$ stands for exploitation costs or the costs of the equipment operation. The price is given in USD because it is a standard in marine transportation.

The simplified model consists of a single refrigerating chamber, the influence of intentional or unintentional ventilation, heat dissipation from human work in the chamber, lights, ventilator dissipation are all neglected and only the heat gain through the insulation is considered. Such a simplification is used because for any other model validating each heat gain the exact design of the provision system and its usage should be known. Some of the actual heat gains are unpredictable: number of entrances, would the person switch on the lights or not, how often would the food be loaded etc. Using such a simplification the investment costs are given in the expression

$$
I=C_{\text {comp }}+C_{\text {cond }}+C_{\text {TXV }}+C_{\text {evap }}+C_{\text {pipe }}+C_{\text {refrig }}+C_{\text {insull }}
$$

where $C_{\text {comp }}$ [\$] stands for the price of the compressor, $C_{\text {cond }}$ [\$] stands for the price of the condenser, $C_{T X V}$ [\$] stands for the price of the expansion valve(s), $C_{\text {evap }}[\$]$ stands for the price of the evaporator(s), $C_{\text {pipe }}[\$]$ stands for the price of the piping including all controlling and regulating elements, $C_{\text {refrig }}[\$]$ stands for the price of the refrigerant and, $C_{\text {insul }}[\$]$ stands for the price of the insulating material. By refrigerating capacity determination, the capacity of the compressor is determined and from it the capacity of every other systems element. Hence, the capacity and price of every refrigerating system's element is proportional to the capacity of the compressor, the equation (2) can be simplified and gives

$$
\begin{aligned}
& I=C_{\text {comp }}+A \cdot C_{\text {comp }}+B \cdot C_{\text {comp }}+C \cdot C_{\text {comp }}+D \cdot C_{\text {comp }}+ \\
& +E \cdot C_{\text {comp }}+F \cdot C_{\text {comp }}+C_{\text {insul }}
\end{aligned}
$$

or, if simplified even further

$$
I=C_{\text {comp }}(1+A+B+C+D+E+F)+C_{\text {insul }}
$$

where coefficients $A, B, C, D, E$ and $F$ stand for linear dependence of the element price on the compressor price. If the sum of the coefficients in brackets are denominated as $K$ the equation (4) becomes

$$
I=K C_{\text {comp }}+C_{\text {insul }}
$$

In the expression (5) the compressor price results from the expression of the compressor's real cooling capacity given with

$$
Q_{\text {real }}=\frac{24 Q_{o}}{t}
$$

The value $t[\mathrm{~h}]$ stands for the real operation time of the compressor during one day (usually the 24 hour period is selected) and $Q_{o}[\mathrm{~W}]$ stands for the theoretical capacity of the compressor in accordance with the expression bellow

$$
Q_{o}=k \cdot A \cdot \Delta \vartheta
$$

Here $k\left[\mathrm{WK}^{-1} \mathrm{~m}^{-2}\right]$ stands for the heat transfer coefficient through the insulation, $A\left[\mathrm{~m}^{2}\right]$ stands for the outer surface of the cooling chamber and, $\Delta \vartheta[\mathrm{K}]$ stands for the temperature difference between the chamber temperature and the surrounding temperature. In the expression (7) the heat transfer coefficient is well known and is given as

$$
k=\frac{1}{\frac{1}{\alpha_{1}}+\frac{\delta_{\text {insul }}}{\lambda_{\text {insul }}}+\frac{1}{\alpha_{2}}}
$$

The provision plant usually consists of several chambers, two of them (meat and fish) having temperatures of approximately $-20^{\circ} \mathrm{C}$, and the others with the operating temperatures above $0^{\circ} \mathrm{C}$ (from +4 till $+13^{\circ} \mathrm{C}$ ). The surrounding temperature is set as a tropical one, namely $35^{\circ} \mathrm{C}$. In accordance with the above simplification, the mediate temperature of a single chamber is set as $0^{\circ} \mathrm{C}$. Hence, the temperature difference in the equation (7) is determined as $35 \mathrm{~K}$.

If the specific price of the compressor is $c_{\text {comp }}[\$ / W]$, the total price of the compressor is given in the expression

$$
C_{\text {comp }}=Q_{\text {real }} \cdot c_{\text {comp }}
$$

The total price of the insulating material is given in the expression below

$$
C_{\text {insul }}=m_{\text {insul }} \cdot C_{\text {insul }}
$$


where $c_{\text {insul }}[\$ / \mathrm{kg}]$ stands for the specific price of the insulating material and, $m_{\text {insul }}[\mathrm{kg}]$ stands for the total mass of it, calculated in accordance with

$$
m_{\text {insul }} \approx A \cdot \delta_{\text {insul }} \cdot \rho_{\text {insul }}
$$

Here the $A\left[\mathrm{~m}^{2}\right]$ is the outer surface of the chamber, $\delta_{\text {insul }}[\mathrm{m}]$ stands for the thickness of the insulation and, $\rho_{\text {insul }}$ $\left[\mathrm{kg} / \mathrm{m}^{3}\right]$ stands for the density of the insulating material.

The implementation of the equations (6) to (11) into the equation (5) gives

$I=\frac{24\left[\left(\frac{1}{\frac{1}{\alpha_{1}}+\frac{\delta_{\text {insul }}}{\lambda_{\text {insul }}}+\frac{1}{\alpha_{2}}}\right) \cdot A \cdot \Delta \vartheta\right]}{t} \cdot c_{\text {komp }} K+A \cdot \delta_{\text {insul }} \cdot \rho_{\text {insul }} \cdot c_{\text {insul }}$

The simplest way of writing the equation (12) is

$$
I=\frac{K_{1}}{K_{2}+K_{3} \cdot \delta_{\text {insul }}}+A \cdot \delta_{\text {insul }} \cdot \rho_{\text {insul }} \cdot c_{\text {insul }}
$$

where the constants in the equation are

$$
\begin{aligned}
K_{1} & =\frac{24 A \cdot \Delta \vartheta}{t} \cdot c_{\text {komp }} K \\
K_{2} & =\frac{1}{\alpha_{1}}+\frac{1}{\alpha_{2}} \\
K_{3} & =\frac{1}{\lambda_{\text {insul }}}
\end{aligned}
$$

The exploitation costs is given in the expression below

$$
E=\frac{1}{\varepsilon} G \cdot t \cdot Q_{\text {real }}
$$

where $\varepsilon$ is the coefficient of the performance of the compressor, $t$ represents again the operating hours of the compressor, $G$ is a constant considering the electric motor and the compressor's efficiency and the price of the electric energy $c_{E E}[\$ / \mathrm{Wh}]$, given in the equation

$$
G=\eta_{\text {comp }} \cdot \eta_{e m} \cdot c_{E}
$$

The implementation of the equations (6) to (8) into the (15) one and with a few simplifications results in the equation

$$
E=\frac{24 \cdot A \cdot \Delta \vartheta}{\varepsilon\left(K_{2}+K_{3} \delta_{\text {insul }}\right)} G
$$

If the equations (13) and (17) are implemented into the basic equation (1) it could be given as

$$
U=f\left(\delta_{\text {insul }}\right)
$$

If the first derivative of function (18) is equalized to 0 , the value of the optimal insulation layer thickness is given in the following expression

$$
\delta_{\text {insul, opt }}=\frac{\sqrt{\frac{K_{1}+\frac{24 A \Delta \vartheta G}{\varepsilon} \rho_{\text {insul }} C_{\text {insul }}}{K_{3}}-K_{2}}}{K_{3}}
$$

and, from the optimal insulation layer thickness the optimal refrigerating compressor's capacity is achieved in equations (6) to (8).

\section{Numerical Solution and Graphical Interpretation}

Matlab has been used to create the algorithm for the numerical solution of the problem. Obviously, the analytical solution could not predict the changes of some parameters included, i.e. price of energy or system elements. That is why several calculations have been made with different prices and payback periods. But the other values are used as constant, i.e. volume of the cooling chamber, which is $200 \mathrm{~m}^{3}$.

Figure 1 represents results for the system with all of the elements being twice as costly as the compressor itself, with the price of the energy $20 \mathrm{c} / \mathrm{kW}$ and, with the amortization period of 10 years. Optimal insulation thickness results in $11.85 \mathrm{~cm}$.

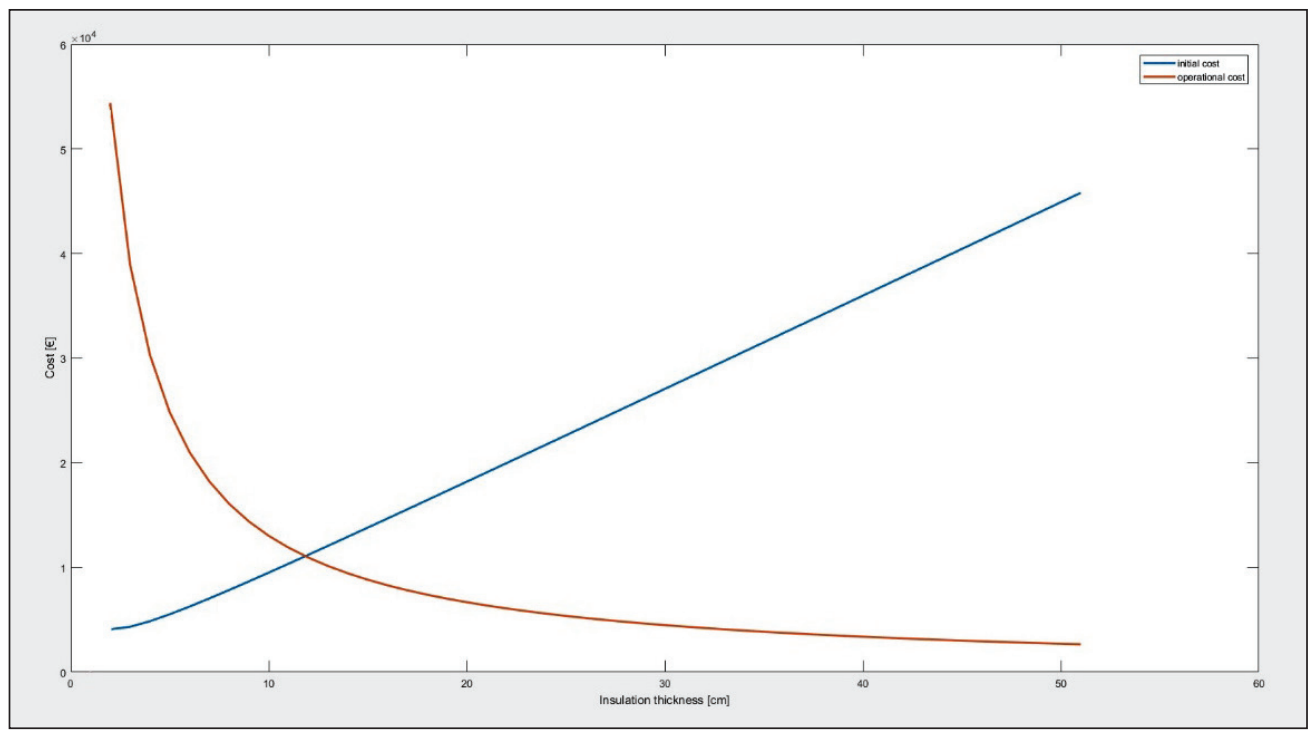

Figure 1 Presentation of the Results with a Presumed Set of Values 1 


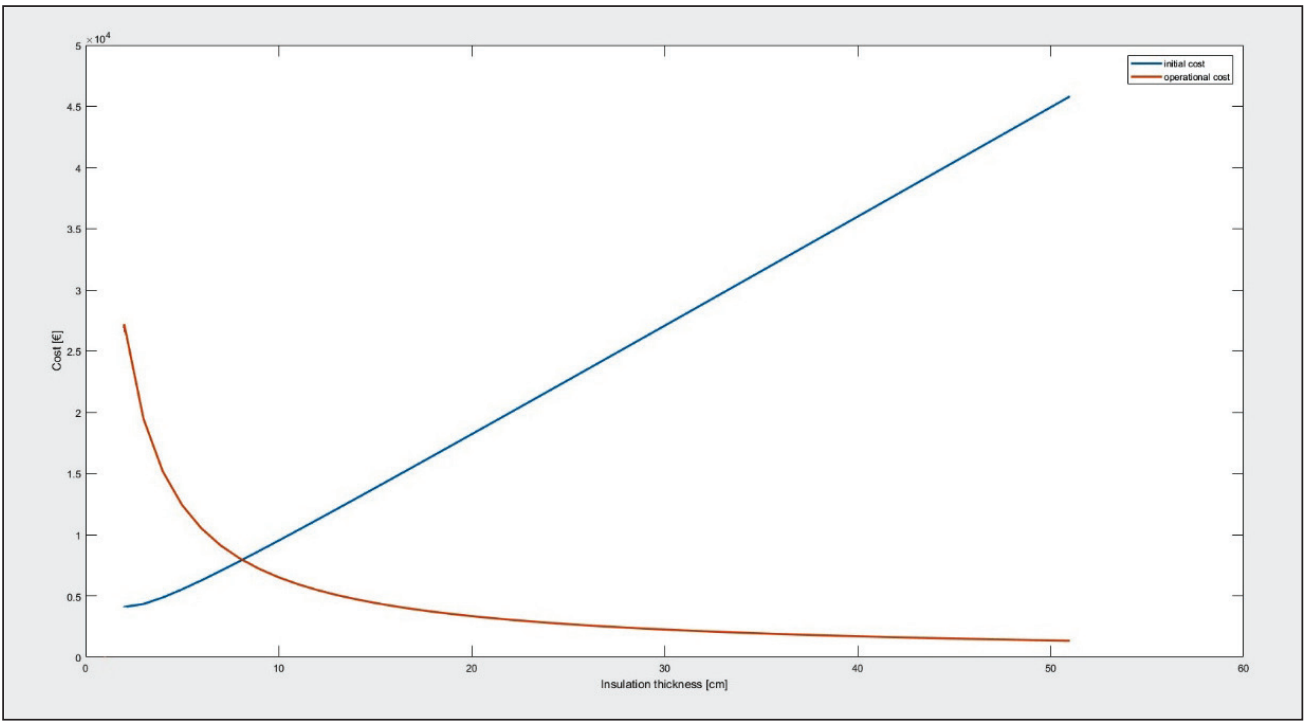

Figure 2 Presentation of the Results with a Presumed Set of Values 2

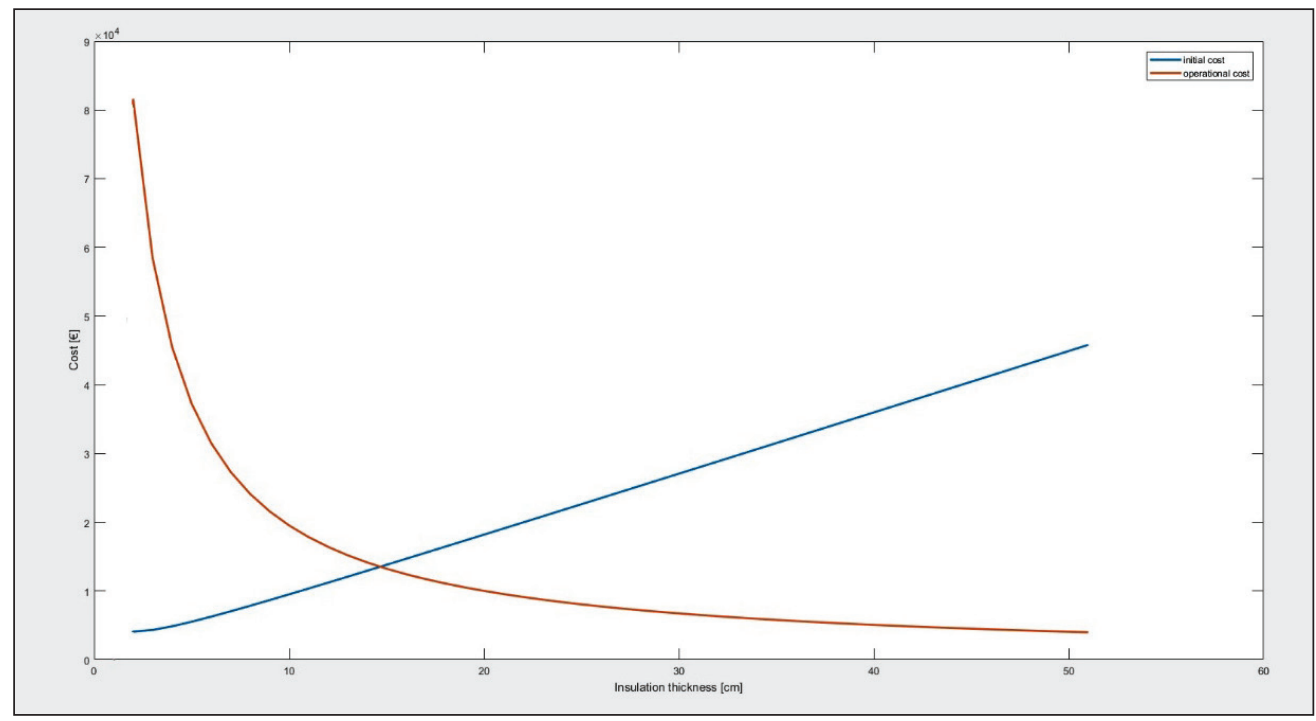

Figure 3 Presentation of the Results with a Presumed Set of Values 3

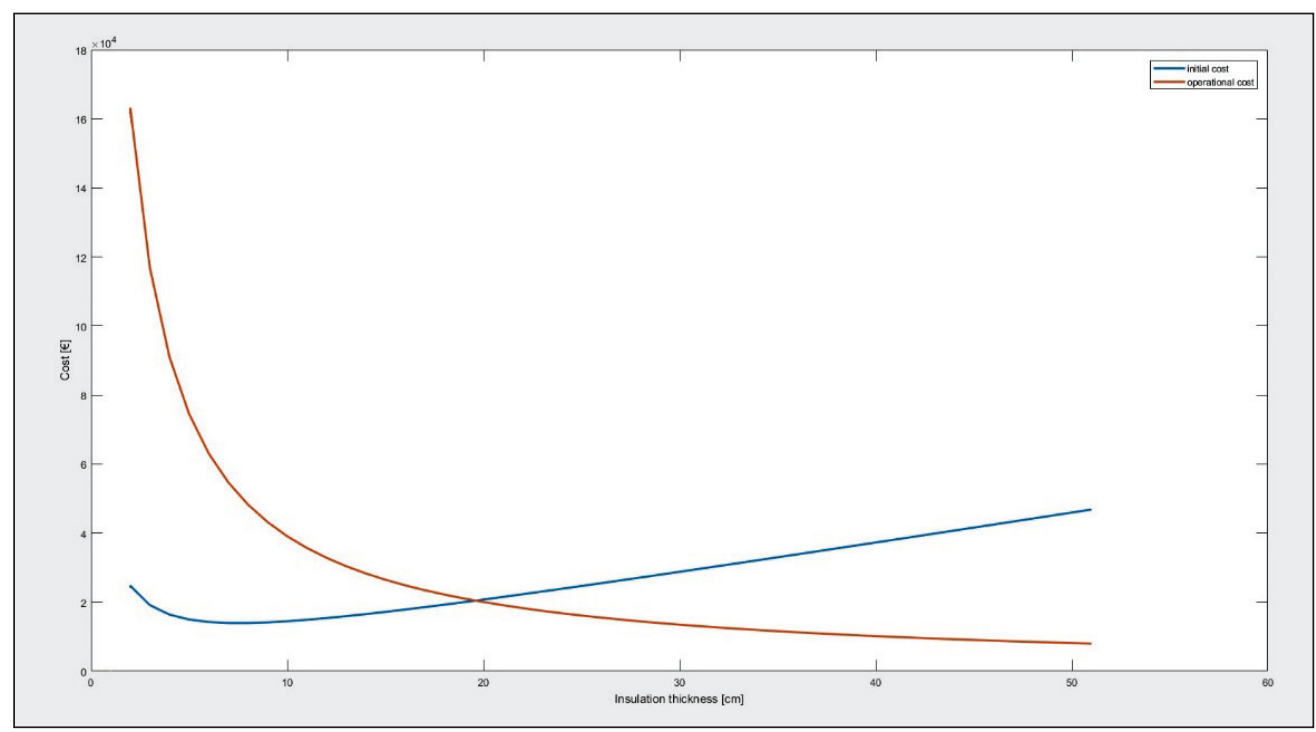

Figure 4 Presentation of the Results with a Presumed Set of Values 4 


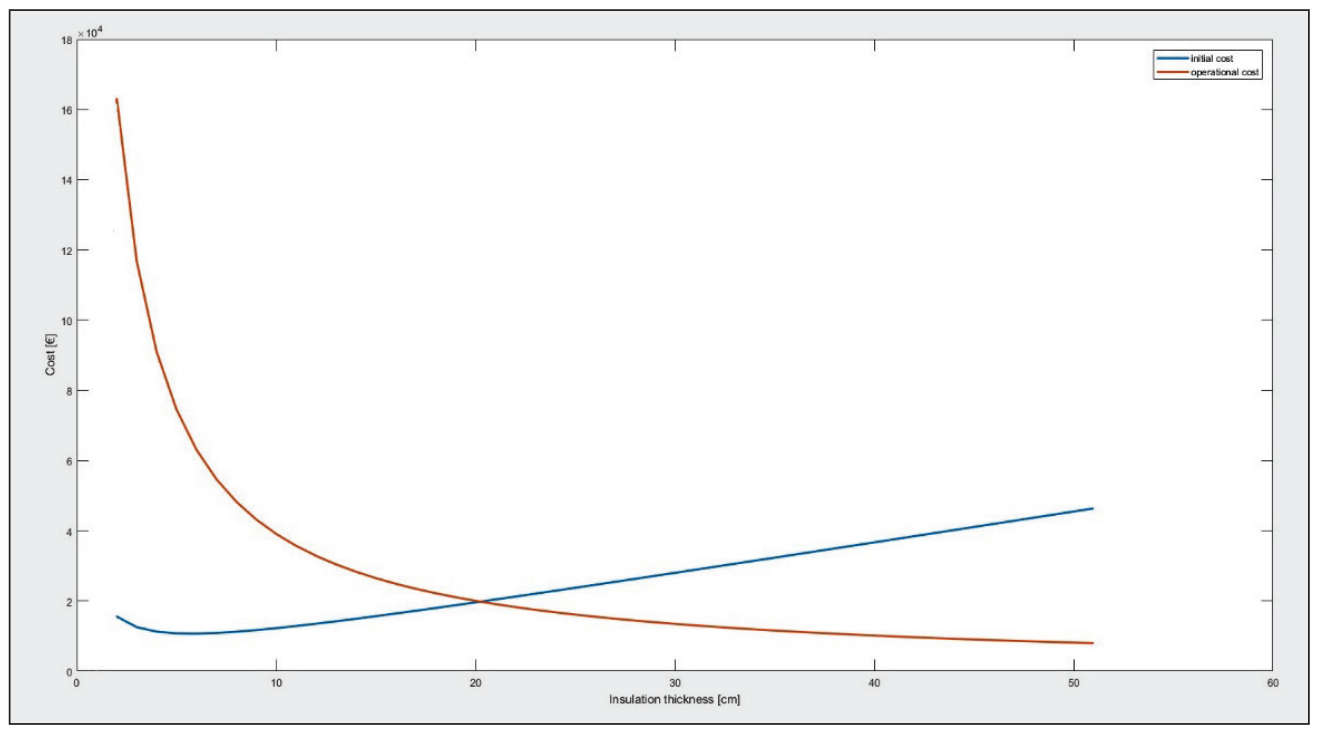

Figure 5 Presentation of the Results with a Presumed Set of Values 5

For the same price of the system (compressor and other elements), the same amortization period and the price of the energy half of the price from the first model, the algorithm has given the optimal insulation thickness of $8.1 \mathrm{~cm}$. The numerical solution is given on Figure 2 .

The third solution has been created for the energy price of $30 \mathrm{c} / \mathrm{kW}$, the same price of the system and the same amortization period. The optimal insulation thickness has reached $14.7 \mathrm{~cm}$.

The next model has used the energy price of $20 \mathrm{c} / \mathrm{kW}$, the same price of the system as in the first one, but with the oversized compressor because of other heat losses from the refrigerated chamber (10 times the compressor from the first model) and, with the amortization period shorten to three years only. The optimal insulation thickness has resulted in $19.6 \mathrm{~cm}$. The numerical solution is shown on Figure 4.

The last model has used the energy price of $20 \mathrm{c} / \mathrm{kW}$, the price of all other system elements together being 1.2 the price of the compressor, the compressor's capacity 10 times of the compressor from the first model and the amortization period of three years. The solution is presented on Figure 5. The optimal insulation resulted $20.25 \mathrm{~cm}$.

Using the iterative method through expressions (6) to (8) and the same computer, the algorithm optimal compressor capacities have been calculated. Those values are presented in Table 1.

Table 1 Optimal Compressor Capacities

\begin{tabular}{|c|c|}
\hline $\begin{array}{c}\text { Optimal insulation layer } \\
\text { thickness [cm] }\end{array}$ & $\begin{array}{c}\text { Refrigerating compressor } \\
\text { optimal capacity [kW] }\end{array}$ \\
\hline 11.85 & 21.5 \\
\hline 8.1 & 31.4 \\
\hline 14.7 & 17.3 \\
\hline 19.6 & 13 \\
\hline 20.25 & 12.6 \\
\hline
\end{tabular}

\section{Conclusion}

The energy efficiency of complex power plants should always be considered. The ship's power plant is no exception, quite the opposite. However, in the past, there were some prevailing factors used during the process of design, such as safety and availability. Not that those are not important any more, but the efficiency of every ship's component has become important because a reduced efficiency usually means more pollutants in the marine environment.

The paper deals with a small, but important component on board every ship - refrigerating compressor. Namely, it deals with its optimization. Those compressors emerge in the provision refrigerating plant, air conditioning plants, cargo hold refrigeration and so on. The optimization method applied in this paper is quite simplified and could be used for any kind of refrigerating compressor, provided that some actual values of the refrigeration plant are known. The shortcoming of the presented model, using the thermal load through the walls only, should be overpassed in the future, knowing the actual refrigerating system design.

In this paper, an imaginative cooling space has been used. The mathematical model has calculated an optimal insulation layer thickness and, through it, the optimal refrigerating compressor capacity. Several results have been obtained depending on energy prices and amortization periods. The main purpose of the model however is the indication of the one way of solving the refrigerating compressor optimization.

\section{References}

[1] Kralj, P.: Brodski sustavi mikroklime - automatizacija i optimizacija, Zbornik Pomorskog fakulteta u Rijeci, Rijeka, god. 12 (1998), pp. 197-203. 
[2] Brito, P. - Lopes, P. - Reis, P. - Alves, O.: Simulation and optimization of energy consumption in cold storage chambers from the horticultural industry, Int J Energa environment Eng (2014), doi: 10.1007/s40095-014-0088-2.

[3] Milošević, Š. - Kralj, P.: Simplified Mathematical Model of Vaporization in a Fresh Water Vacuum Distillation Generator, Proceedings from the Symposium "Energy and Environment", Opatija, 1996, pp. 237-244.

[4] Milošević Š. - Kralj, P.: Vacuum distillation fresh water generator application on board ship, ELMAR '98, Zadar, 1998., pp. 196-200.

[5] Kralj, P. - Martinović, D. - Tudor, M.: Analysis of thermodynamic and technological basics of the marine fresh water generator model, Desalination and water Treatment, (2017) 1-6, pp. 180-185, doi: 10.5004/dwt.2017.21552.

[6] Kralj, P.: Prilog raspravi o zaštiti morskog okoliša, Zbornik radova Pomorskog fakulteta, Rijeka, Vol. 11 (1997), pp. 119-128.

[7] Martinović, D. - Kralj, P. - Bukša, A.: Minimization of energy and exergy consumption by application of combined plant on maritimes isolated communities, ELMAR '98, Zadar, 1998, pp. 22-25.

[8] Kralj, P. - Bukša, A. - Martinović, D.: Razvoj brodskih rashladnih sustava - utjecaj propisa o zaštiti okoliša, Pomorstvo, Rijeka, Vol. 13 (1999), pp. 211-222.

[9] Martinović, D. - Tireli, E. - Kralj, P.: Stanje i razvoj integralnog upravljanja brodom, Zbornik radova Međunarodnog znanstveno-stručnog simpozija o prometnim znanostima, Portorož, 1997, pp. 129-134.

[10] Martinović, D., Tireli, E., Kralj, P.: Integration Control and Supervision into an Intelligent Machinery Management System, 2nd Congress; Transport Traffic Logistics, Proceedings, Portorož, Slovenia, 2000, pp. 349-353, ISBN 86-435-03525.

[11] Kralj, P.: Prijedlog sustava upravljanja vakuumskog generatora slatke vode, Zbornik radova Pomorskog fakulteta, Rijeka, Vol. 10 (1996), pp. 83-90.

[12] Brozičević, M. - Martinović, D. - Kralj, P.: Techno-economic analysis of the cogeneration process on board ships, Journal os Sustainable Development of Transport and Logistics, Vol. 2, No. 1, 2017, doi: 10.14254/jsdtl.2017.2-1.1.

[13] Tudor, M. - Bukša, A. - Kralj, P.: Maintenance of ship's systems, Pomorstvo, Rijeka, Vol. 18 (2004), pp. 29-42.

[14] Tudor, M. - Kralj, P.: Utjecaj rizika kvara na računalni odabir pristupa održavanju brodskih sustava, Pomorstvo, Rijeka, Vol. 14 (2000), pp. 43-52.

\section{Appendix}

Listing of Matlab computer application:

clear

clc

$\mathrm{d}=0.01 \quad \%$ početna debljina izolacije

$\mathrm{t}=24 \quad \%$ sati rada kompresora $\mathrm{u}$ danu

$\mathrm{L}=10 \quad$ \%koeficijent topliske vodljivosti zraka

$\mathrm{Lm}=0.026 \quad \%$ koeficijent toplinske provodljivosti izolacije

$\mathrm{A}=280 \quad \%$ površina komore

$\mathrm{q}=35 \quad$ \%razlika unutarnje i vanjske temperature

$\mathrm{Ck}=0.1135 \%$ cijena kompresora $(€ / \mathrm{W})$

$\mathrm{K}=2 \quad$ \%koeficijent cijene armature u odnosu na cijenu kompresora

$\mathrm{R}=40 \quad$ \%gustoca izolacije

$\mathrm{Ci}=8 \quad \%$ cijena izolacije $(€ / \mathrm{kg})$

$\mathrm{Cs}=0.0002 \quad \%$ cijena elektricne energije (€/Wh)

$\mathrm{G}=10 \quad \%$ broj godina na kojem se promatra

$\mathrm{e}=3 \quad \% \mathrm{COP}$

for $\mathrm{i}=2: 51$

$$
\begin{aligned}
\mathrm{d}(\mathrm{i})= & d(\mathrm{i}-1)+0.01 \\
\mathrm{y}(\mathrm{i})= & \left(\left(24^{*} \mathrm{~A}^{*} \mathrm{q}^{*} \mathrm{Ck} \mathrm{k}^{*} \mathrm{~K}\right) / \mathrm{t}\right) *(1 /((1 / \mathrm{L})+ \\
& (\mathrm{d}(\mathrm{i}) / \mathrm{Lm})+(1 / \mathrm{L})))+\left(\mathrm{A}^{*} \mathrm{~d}(\mathrm{i})^{*} \mathrm{R}^{*} \mathrm{Ci}\right) \\
\mathrm{x}(\mathrm{i})= & \left(\mathrm{t}^{*} \mathrm{~A}^{*} \mathrm{q}^{*} 0.94^{*} 0.98^{*} \mathrm{Cs} \mathrm{s}^{*} 35^{*} \mathrm{G}\right)^{*} \\
& \left(1 /\left(\mathrm{e}^{*}((1 / \mathrm{L})+(1 / \mathrm{L})+(\mathrm{d}(\mathrm{i}) / \mathrm{Lm}))\right)\right)
\end{aligned}
$$

end

figure

plot (y, 'linewidth', 2)

hold

plot (x, 'linewidth', 2)

xlabel ('Insulation thickness [cm]')

ylabel ('Cost $[€]$ ')

legend ('initial cost', 'operational cost') 